\title{
Motor neuropathy with multiple conduction blocks associated with TNF-alpha antagonist
}

\author{
Paulo Eduardo Mestrinelli Carrilho ${ }^{1}$, Allan César Faria Araújo², \\ Orival Alves', Paulo Gustavo Kotze ${ }^{3}$
}

Infliximab, eternecept and adalimum$\mathrm{ab}$ are tumour necrosis alpha factor (TNFalpha) antagonists which recently became part of several auto-immune diseases therapeutic arsenal, mainly in rheumatoid arthritis, ankylosing spondilitis, psoriatic arthritis, as well as inflammatory bowel diseases ${ }^{1,2}$. TNF-alpha plays a crucial role in many aspects of immune system development, immune-response regulation and T-cell-mediated tissue injury. It is a cytokine with both pro-inflammatory and immunoregulatory properties and is involved in normal inflammation and immune responses. TNF-alpha is an important growth factor for prothymocytes and thimocytes, and thereby influences the generation of the $\mathrm{T}$-cell repertoire. In the peripheral immune system, TNF-alpha participates in antigen-presenting cellfunction and in regulating apoptosis of potentially auto-reactive T- cells. So that, immunological complications with drugs that antagonize TNF-alpha receptors were expected to occur. Demyelinating peripheral motor neuropathy is one of them, but it is relatively uncommon ${ }^{3-9}$.

We report a patient who had a severe form of Crohn's disease, who developed a peripheral neuropathy with multiple motor conduction blocks at atypical sites, with axonal damage signs, probably associated with infliximab treatment.

\section{CASE}

The present report was written after patient information and with her agree- ment with the data publication. She is a 64-year-old woman with a severe histologicaly defined Crohn's disease started to be treated with infliximab $(5 \mathrm{mg} /$ $\mathrm{Kg}$ ) with improvement of all symptoms after the first infusion. Almost immediately after the overall fifth dose of infliximab, she developed right radial, right ulnar and left posterior tibial nerve palsies. Electroneuromyography (Figs 1 and 2) disclosed a predominant motor neuropathy in the nerves described above with multiple motor conduction blocks pattern, also associated with fibrilations and reduction of motor unit recruitment in the muscles innervated by those nerves. Non-significant amplitude decrease of sensory potentials was noticed. The rest of laboratory investigation was unremarkable, and included FAN, ANA, P-anca, C-anca, anti-DNA, anti-GM1, thyreoid hormones, blood glucosis, renal and hepatic functions, HIV1 and 2, HBV and HCV serology, vitamine B12. Infliximab infusions were interrupted and the patient obtained a gradual, but incomplete, recovery. After 6 months of follow-up, the patient still had a slight radial and ulnar nerves paresis, but an almost complete clinical improvement was observed in the left posterior tibial nerve.

\section{DISCUSSION}

The advent of TNF-alpha antagonists brought new horizons on treatment of several auto-immune disorders, mainly in rheumatoid arthritis and inflammatory bowel diseases. Two distinct receptors
Porrespondence Rua Santa Catarina 925 - Neuroclínica 85801-040 Cascavel PR - Brasil E-mail: pemcarrilho@gmail.com

Received 20 April 2009

Received in final form 27 July 2009

Accepted 11 August 2009

\section{NEUROPATIA MOTORA COM MÚLTIPLOS BLOQUEIOS DE CONDUÇ̃̃o ASSOCIADA A ANTAGONISTA DE TNF-ALFA}

${ }^{1}$ Professor da Disciplina de Neurologia e Neurocirurgia do Curso de Medicina da Universidade Estadual do Oeste do Paraná - UNIOESTE, Paraná, Brasil;; ${ }^{2}$ Professor da Disciplina de Clínica Cirúrgica do Curso de Medicina da Universidade Estadual do Oeste do Paraná - UNIOESTE, Paraná, Brasil; ${ }^{3}$ Chefe do Serviço de Coloproctologia do Hospital Universitário Cajuru - PUCPR, Paraná, Brasil. 

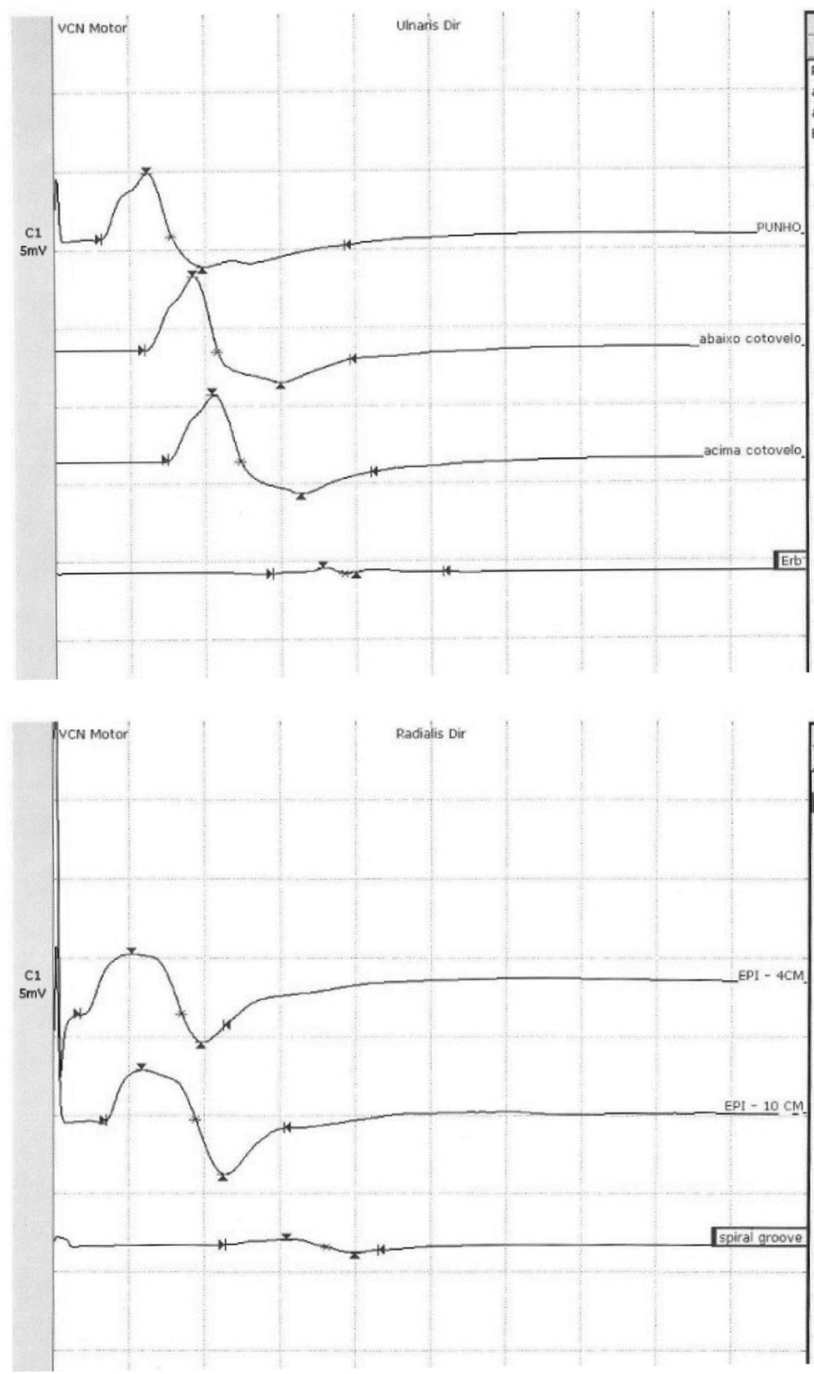
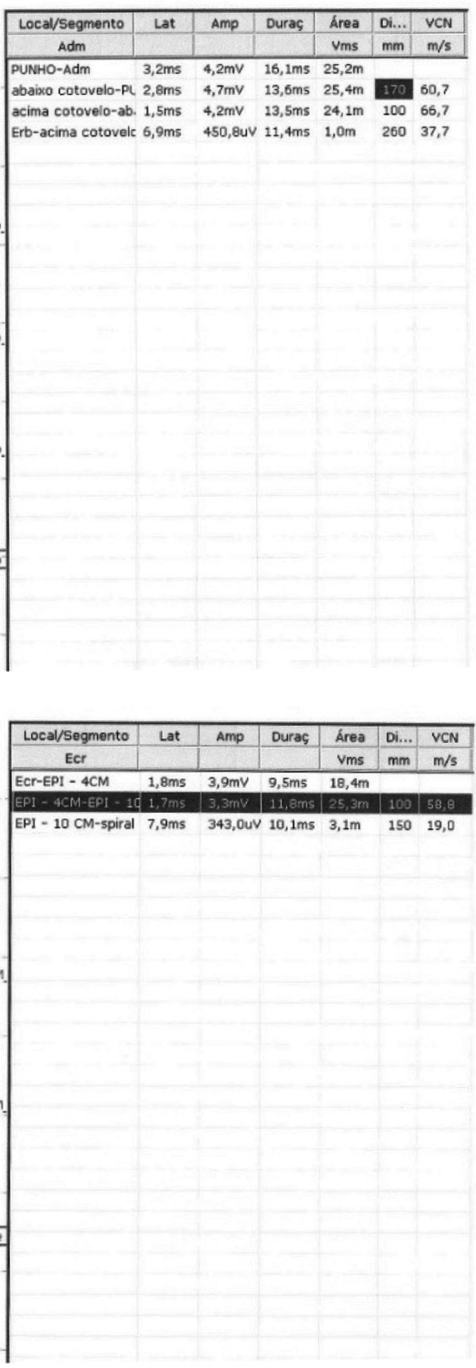

Fig 1. Right ulnar nerve motor conduction block at axila and right radial nerve motor conduction block at the arm. for TNF-alpha (p55 and p75) exist naturally as monomeric molecules on cell surfaces and in soluble forms. Biological activity of TNF-alpha is dependent upon binding to either cell surface receptor ${ }^{10}$. Nowadays, two different groups of anti-TNF-alpha are available: the eternecept group and monoclonal antibodies group. The former is a soluble, dimeric fusion protein of the human p75 TNF receptor linked to the Fc portion of human IgG1. The second group is composed by infliximab and adalimumab. Adverse events are commonly slight, generally injection site inflammatory reaction, flu-like symptoms and headache ${ }^{4}$. Collateral effects secondary to inadequate immune system modulation are quite rare, but drug-induced lupus and demyelinating syndromes are described ${ }^{4}$. Such reactions are expected to occur in about 233 subjects per million of treated patients ${ }^{3,4}$. Central nervous system autoimmune demyelinating disorders include anterior and posterior optic neuritis and worsening of multiple sclerosis ${ }^{4}$. Peripheral nervous disorders include Guillain-Barré and Miller-Fischer syndromes, chronic inflam- matory demyelinating polyradiculoneuropathy, mononeuritis simplex and multiplex, axonal sensory-motor polineuropathy and even motor neuropathy with multiple conduction blocks ${ }^{4-8}$. Two explanations about these anti-TNF-alpha collateral effects are discussed in the literature ${ }^{4}$ : a direct toxic drug aggression or a specific autoantibody production and $\mathrm{T}$ cell immune system derangement induced by this group of agents. The real cause of such undesirable events is obscure, but the second hypothesis is well accepted. It is logical to argue that pathogenesis of such type of neuropathy should include a myelin aggression both by inadequate T-cell dependent immune system activation and a humoral antibody production. Also, an ischemic damage from vasculitis and inhibition of axon support signals are suspected to be involved $^{4}$. It is important to know that TNF-alpha probably has a pro-inflammatory function in the pathogenesis of Guillain-Barré syndrome ${ }^{4,10}$ (serum levels correlate with disease activity and severity). TNF-alpha deficiency leads to failed regression of myelin-specific T-cell reac- 


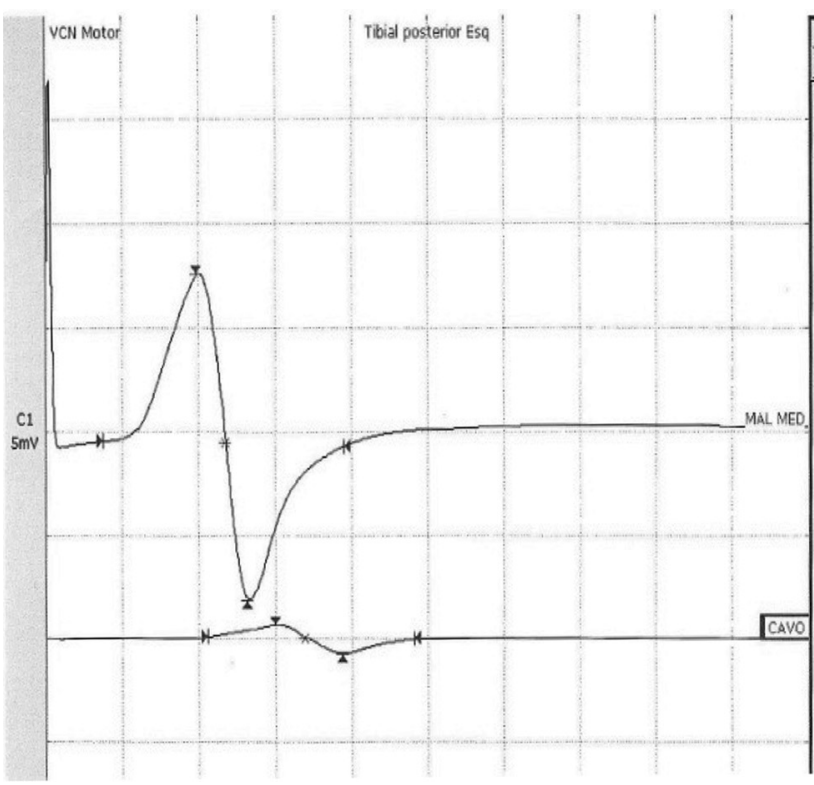

Fig 2. Left posterior tibial nerve motor conduction block at leg. tivity and prolonged survival of activated $\mathrm{T}$ cells. When endogenous TNF-alpha is blocked by repeated injections of a TNF-alpha antagonist, T-cell-proliferative responses and cytokine production are enhanced. The prolonged administration of TNF-alpha antagonists is thought to enhance autoimmune responses by altering antigen-presenting cell function, potentiating T-cell receptor signaling, and decreasing apoptosis of auto-reactive $\mathrm{T}$ cells.

According to proposed criteria $^{11}$, an illness, like neuropathy, can be considered as drug-induced or environmentally associated based on: [1] temporal closed association; [2] lack of likely alternative explanations; [3] stabilization or improvement by interrupting exposure to the presumed inciting agent; [4] rechallenge; [5] biological plausibility; [6] analogy; [7] dose responsiveness; [8] specificity. To report findings of a possible causal relationship between exposure and clinical syndrome, at least 4 of the 8 attribution elements should be present. Based on these criteria, the motor neuropathy described in the present article is probably very well correlated with infliximab.

Paradoxically, it is interesting to report that preliminary observations of a single retrospective uncontrolled study suggested possible efficacy of etanercept $\left(\right.$ Enbrel $\left.^{\circ}\right)$ treatment in selected patients with CIDP, or its variants, who were refractory to or intolerant of conventional therapies $^{12}$. In another case report ${ }^{13}$, mononeuritis multiplex (demyelinating and axonal) complicated active Crohn's disease and was treated with a series of infliximab infusions. The manifestations of neuropathy improved clinically after the first infusion, and after 22 weeks, the electrophysiological studies returned to normal. The present case differs from that, once the symptoms of intestinal disease improved markedly with infliximab and the neuropathy developed only after repeated series of infusions. Eventually, Crohn's disease may predispose such type of complication with anti-TNF-alpha agents, once this entity is also rarely associated with mononeuritis multiplex by itself.

\section{REFERENCES}

1. Feagan BG, Enns R, Fedorak RN, et al. Infliximab for the treatment of Crohn's disease:efficacy, safety and pharmacoeconomics. Can J Clin Pharmacol 2001; 8:188-198.

2. Hamilton K, Clair EW. Tumor necrosis factor alpha blockade: a new era for the effective management of rheumatoid arthritis. Expert Opin Pharmacother 2000;1:1041-1052.

3. Rodriguez-Escalera C, Belzunegui J, Lopez-Dominguez L, Gonzalez C, Figueroa M. Multifocal motor neuropathy with conduction block in a patient with rheumatoid arthritis on infliximab therapy. Rheumatology 2005;44:132-133.

4. Stübgen JP. Tumor necrosis factor-alpha antagonists and neuropathy. Muscle Nerve 2008;37:281-292

5. Singer OC, Otto B, Steinmetz H, Ziemann U. Acute neuropathy with multiple conduction blocks after TNF-alpha monoclonal antibody therapy. Neurology 2004;63:1754.

6. Shin I-S J, Baer AN, Kwon HJ, Papadopoulos EJ, Siegel JN. Guillain-Barré and Miller-Fisher syndromes occurring with tumor necrosis factor alpha antagonist therapy. Arthritis Rheum 2006;54:1429-1434.

7. Richez C, Blanco P, Lagueny A, Schaeverbeke T, Dehais J. Neuropathy resembling CIDP in patients receiving tumor necrosis factor-alpha blockers. Neurology 2005;64:1468-1470.

8. Richette P, Dieudé P, Damiano J, et al. Sensory neuropathy revealing necrotizing vasculitis during infliximab therapy for rheumatoid arthritis. J Rheumatol 2004;31:2079-2081.

9. Jarand J, Zochodne DW, Martin LO, Voll C. Neurological complications of infliximab. J Rheumatol 2006:33:1018-1020.

10. Liu J, Marino MW, Wong G. TNF is a potent anti-inflammatory cytokine in autoimmune-mediated demyelination. Nat Med 1998;4:78-83.

11. Miller FW, Hess EV, Claw DJ, et al. Approaches for identifying and defining environmentally associated rheumatic disorders. Arthritis Rheum 2000;43:243-249.

12. Latov N, Sherman WH. Improvement with etanercept (Enbrel) in chronic inflammatory demyelinating polyneuropathy. Ann Neurol 2000;48:473.

13. Rodinò S, Saccà N, D'Amico T, Fragomeni A, Giglio A. Severe polyneuropathy complicating active Crohn's disease: rapid response to infliximab. GUT 2003; 52:1070. 